\title{
Improving Nutrient Removal in Constructed Wetland Wastewater Treatment
}

\author{
Mohammed Hassan Al-Saad, Alaa Ibrahim Elaibi, Inas Sami Mageed \\ College of Engineering Nahrain University
}

\section{Introduction:}

$T_{\text {his work is a continuation of }}$ the research work carried out by investigator [1] to treat $2 \mathrm{~m}^{3} /$ day municipal wastewater using the Vertical Flow Reed Bed constructed wetland pilot plant which was designed, constructed, on Al-Nahrain University ground, and ran (past) 2006-2009 [1].

The use of constructed wetlands for wastewater treatment is an alternative to conventional wastewater treatment technologies and is aimed at producing a sustainable and robust treatment system based on a complex natural ecosystem [2].

Constructed wetland treatment systems essentially comprise self-contained engineering constructed eco-systems.

They utilize particular combination of plants, soil, bacteria, substrate and hydraulic flow system. The treatment is based upon the cleansing power of three main elements, micro-organisms created in the system, the physical and chemical properties of the substratum layers, and finally the reed plants $[2,3,4]$.

The function and properties of each cleansing element can be summarized as follow:

- Microbial activity:

Micro-organisms attach themselves to the outside of the gravel or soil particles and to the plants and plant roots. These organisms metabolize polluting chemicals, degrading and mineralizing them. Commonly, reed bed constructed wetlands are used to degrade sewage, but with higher retention times and fully mature reed plants it can be used to remove phenols, methanol, acetone, PCB, dyestuffs, amines and glycols from a range of industrial effluents [5]. For example, after the Gulf War, in the oil-polluted sands of the Kuwait desert, 


\section{Journal of Petroleum Research \& Studies}

the first cleaning processes took place around the roots of annual plants, where oil-eating micro-organisms cleaned both the roots and the sand particles sticking to them [6]

-Reed plats

The reed plants have the following functions [7]:

(1)- The very extensive root system creates channels for the water to pass through and provide the means for secondary restructuring of the substrate in the system.

(2)- The roots introduce oxygen down into the body of the substrate layers and provide an environment where aerobic bacteria can thrive. These organisms are necessary for the breakdown of many types of compound, in particular in the oxidation of ammonia to nitrate, the first step in the biological breakdown of this compound.

Physical

Sedimentation

Filtration

Adsorption

Volatilization
Chemical

Filtration

Precipitation

Adsorption

Hydrolysis reactions

Oxidation - reduction

Photochemical

reactions
(3)- The reed plants themselves take up a certain amount of nutrient from the waste water. Most degradation of nutrients is, however, undertaken by the microbes.

The choice of substrate media, gravel, soil or sand, is dependent upon the particular application requirements. Gravel is less active microbiologically, but allows a faster throughput of water. Certain soil minerals actually encourage the deposition of metal ions, phosphate and sulfate. The ability of reed plants to keep the wastewater oxygenated also encourages the deposition of insoluble metal ions precipitate on the substrate media.

The components making the wetland system i.e. bacteria, substrate, plants and hydraulic flow are connected by a number of physical, chemical and biological transfer processes as shown below $[5,8]$ 


\subsection{Contaminant removal mechanism:}

The principal of the constructed

wetland is to activate microbial processes that stimulate the natural breakdown of polluting compounds in a specific wastewater situation. This is possible due to the special characteristics of wetland plants, such as reeds, which can transfer substantial amount of atmospheric oxygen through to their root systems encouraging an extraordinary quantity and species diversity of micro-organisms to flourish around their roots.

The breakdown of contaminants is achieved by the controlled seepage of the wastewater borne pollutants through the root zone of the reed plants. Organic pollutants are broken down as a food source by microorganisms and the plants, while other contaminants, such as metals and PCBs, are fixed in the humic acid (and via cat-ion exchange bonds) in the mineral substrates in which the reed plants are rooted. This cation exchange ability appears to stem from the presence of carboxyl groups in the cellular layers of the reed, and appears to function whether the plant material is alive or dead [8].

Organic material breakdown may occur via either aerobic andlor anaerobic processes $[7,8]$. The balance between these processes tends to be determined by the organic loading rate and the oxygen supply. In Reed Bed constructed wetlands these two factors are controlled and supplied to the system as follows:

-The organic loading is primarily controlled by the influent wastewater The oxygen supply is controlled via, the air-bed surface exchange, the photosynthesis of the algal bio-films attached to the surface of reed plants and the internal gas transport system of reed plants that provides a source of oxygen inside the wetland substrate through their root and because the roots of reed plants are large and mostly hollow, when the roots die and breakdown they leave significant conduits for the mass exchange of water and gases between the atmosphere and substrate of the reed bed. This oxygen leakage enhances aerobic processes, 


\section{Journal of Petroleum Research \& Studies}

contributes to the oxidation of surface sediments and is a major mechanism in satisfying organic loads in nitrification processes.

The pathway for the removal of pollutants varies considerably depending on the pollutant and the seasonal variation in the activity of particular mechanisms

\subsection{1- BOD removal:}

W astewater contains a wide range of organic compounds and other oxygen demanding compounds. Organic material in wastewater can vary from readily biodegradable to highly refractory. The BOD of municipal wastewater tends to be dominated by readily biodegradable organic compounds with a $\mathrm{C}: \mathrm{N}: \mathrm{P}$ ratio which is amenable to biological decomposition.

The decomposition pathway by which reed bed engineering constructed wetland organic loads are processed is determined by a balance between the organic load and the supply of oxygen.

If the oxygen supply pathways can satisfy the BOD of the organic load, decomposition will occur via aerobic processes. If the BOD of the organic load consistently exceeds the oxygen supply, decomposition will occur via anaerobic processes $[7,8]$. The balance between aerobic and anaerobic metabolism can significantly influence the major organic processing pathway in a reed bed constructed wetland. In most systems constructed for wastewater treatment, both pathways will be prominent [8]. The degradation and mineralization of organic matter occurs in both the bed substrate and the biofilms on reed plants.

\subsection{2-Suspended Solids removal:}

$W_{\text {astewater suspended solids }}$ consists of a range of organic and inorganic materials but is typically dominated by faecal organic matter and organic particles like bacteria. The density and size of particles can vary considerably.

Suspended solids removal in wastewater treatment wetlands is a fairly rapid physical process $[2,8,9]$. The major removal mechanisms are 
sedimentation, aggregation and surface adhesion.

\subsection{3- Nitrogen removal:}

$\mathrm{N}_{\text {itrogen is a major component of }}$ most wastewaters. Nitrogen exists in the environment in many forms and has a complex cycling pathway. Total nitrogen typically consists of varying proportions of the following: particulate organic nitrogen, dissolved organic nitrogen, ammonium, nitrite and nitrate. Nitrogen gas and nitrous oxide are also important in the nitrogen cycle with the atmosphere being the ultimate sink [9].

The major nitrogen transformation processes responsible for nitrogen loss in wetlands are listed in table 1 below.

Table1. Nitrogen transformation processes in wetland

\begin{tabular}{|l|l|l|}
\hline \multicolumn{1}{|c|}{ Process } & \multicolumn{1}{c|}{ Substrate } & \multicolumn{1}{c|}{ Product } \\
\hline Mineralization & Organic matter & Ammonium \\
\hline Biological Uptake & Ammonium, Nitrate & Organic nitrogen \\
\hline Nitrification (oxidation) & Ammonium & Nitrate \\
\hline Denitrification (reduction) & Nitrate & Nitrogen gas \\
\hline Reduction & Nitrate & Ammonium \\
\hline Volatilization & Ammonium + high $\mathrm{pH}$ & Ammonia gas \\
\hline Nitrogen Fixation & Nitrogen gas & Organic nitrogen \\
\hline
\end{tabular}

Mineralization, biological uptake, result in the net loss of nitrogen from nitrification and dissimilatory nitrate reduction to ammonium (DNRA) are all processes that transform one form of nitrogen to another. In terms of the nitrogen cycle, these mechanisms are conservative processes and operate to cycle nitrogen within a system. Denitrification and ammonia volatilization are export processes and the system. Nitrogen fixation is an important process and returns nitrogen from the atmosphere to the reed bed ecosystem.

Better nutrient removal in the treatment processes of municipal wastewater can be achieved if processes such as, nitrification of ammonium to nitrate, denitrification of 


\section{Journal of Petroleum Research \& Studies}

nitrate to nitrogen gas and ammonia volatilization are improved which will increase the $\mathrm{N}$ removal efficiency of the treatment plant. However $\mathrm{P}$ phosphorus removal does not have an atmospheric component as nitrogen and the phosphorus cycle can be characterized as closed. The removal and storage of phosphorus from wastewater can only occur within the constructed wetland itself by binding inorganic matters and Precipitation of insoluble phosphates with metals.

One way to increase nutrient removal in the existing vertical flow constructed wetland is by recycling portion of the effluent back to the wetland. Moreover, to obtain maximum effect of the recycling process on nutrient removal, the recycling of effluent portion back to the wetland should be designed to give intermittent dosing and in between the already existing arrangement for intermittent dosing of influent wastewater to the wetland.

The removal of $\mathrm{N}$ and $\mathrm{P}$ are not entirely independent of the removal of BOD (Biological Oxygen Demand) and SS (Suspended Solids). When the recycled portion gets in contact with influent wastewater before degradation the SS in the influent will affect the removal of $\mathrm{N} \& \mathrm{P}$, of the recycled portion, because some of these nutrients will be contained in the particulate form. Moreover nitrogen removal shares many traits with $\mathrm{BOD}$ $\&$ COD removal [10] and again when the recycled portion of the effluent containing $\mathrm{NO}_{3}-\mathrm{N}$ is in contact with the influent wastewater early before degradation denitrification process will be enhanced due to the availability of carbon.

\section{$\underline{\text { A-Nitrification }}$}

$\mathrm{N}_{\text {itrification is the biological }}$ conversion of organic and inorganic nitrogenous compounds from a reduced state to a more oxidized state. Nitrification is strictly an aerobic process in which the end product is nitrate $\left(\mathrm{NO}_{3}{ }^{-}\right)$. The nitrification process is limited when anaerobic conditions prevail [9] but it is possible to occur readily down to $0.3 \mathrm{ppm}$ available dissolved oxygen (DO). The recycling 
of treated wastewater with low COD\&BOD will provide the system with DO and when mixing it with influent raw wastewater will result in an increase of DO in the mixture adding to that the quantity of oxygen added to the system due the intermittent recycling pumping process and that entrapped air in the voids of substrate between intermittent dosing will create good aerobic condition. The increase of available DO in the $2 \mathrm{NH}_{4}^{+}+3 \mathrm{O}_{2} \rightleftharpoons 4 \mathrm{H}^{+}+2 \mathrm{H}_{2} \mathrm{O}+$ $2 \mathrm{NO}_{2}^{-}$

$$
2 \mathrm{NO}_{2}^{-}+\mathrm{O}_{2} \rightleftharpoons 2 \mathrm{NO}_{3}^{-}
$$

\section{$\underline{\text { B-Denitrification }}$}

Recycling of effluent containing $\mathrm{NO}_{3}-\mathrm{N}$ and mixing it with the influent wastewater before degradation will enhance the denitrification process which depends on available carbon. Moreover, when the time between recycling doses is made long enough for all the available oxygen to be consumed by the nitrification process than the denitrification process will recycled treated water will provide the right conditions for the nitrification process to take place. The process of nitrification requires two different bacteria, in the presence of Nitrosomonas sp. ammonium is oxidizes to nitrite $\left(\mathrm{NO}_{2}^{-}\right)$and then nitrite oxidizes to nitrate $\left(\mathrm{NO}_{3}{ }^{-}\right)$in the presence of Nitrobacter sp.. The overall nitrification reactions are as follows [9]:

start to take place and the facultative heterotrophic bacteria will use nitrate as acceptor of electrons.

Denitrification is the biochemical reduction of nitrate $\left(\mathrm{NO}_{3}{ }^{-}\right)$and nitrite $\left(\mathrm{NO}_{2}^{-}\right)$to produce the gaseous products nitric oxide $(\mathrm{NO})$, nitrous oxide $\left(\mathrm{N}_{2} \mathrm{O}\right)$ and nitrogen gas $\left(\mathrm{N}_{2}\right)$, with concomitant oxidation of organic matter [11].

The general sequence is as follows [9]:

$$
\mathrm{NO}_{3}{ }^{-} \rightarrow \mathrm{NO}_{2}{ }^{-} \rightarrow \mathrm{NO} \rightarrow \mathrm{N}_{2} \mathrm{O} \rightarrow \mathrm{N}_{2}
$$

The end products, $\mathrm{N}_{2} \mathrm{O}$ and $\mathrm{N}_{2}$ are gases that re-enter the atmosphere. Denitrification occurs intensely in 


\section{Journal of Petroleum Research \& Studies}

anaerobic environments but will also occur in aerobic conditions.

\section{C-Ammonia volatilization}

The ammonia volatilization

process depends largely on the $\mathrm{pH}$ of wastewater, when the $\mathrm{pH}$ value is around 9.3 the ratio between ammonia and ammonium ion will be 1:1 and the chances for ammonia volatilization is high, but when $\mathrm{pH}$ is below 8.0 losses are not serious. When wastewater passes over sand and gravel layers it dissolves calcium from the material and at this instant the alkalinity will increase and ammonia volatilization occur [9].

\subsection{4- Phosphorus removal}

The second major nutrient of concern in wastewater treatment is phosphorus. Phosphorus is not transformed by biological reactions (as is nitrogen). Phosphorus occurs naturally in both organic and inorganic forms. The analytical measure of biologically available orthophosphates is referred to as soluble reactive phosphorus (SR-P). Dissolved organic phosphorus and insoluble forms of organic and inorganic phosphorus are generally not biologically available until transformed into soluble inorganic forms [2]. Phosphorus may be sequestered within a wetland system by the following [12]:

-The binding of phosphorus in organic matter as a result of incorporation into living biomass,

-Precipitation of insoluble phosphates with ferric iron, calcium, and aluminum found in wetland soils.

- Incorporation into biomass:

Higher plants in wetland systems may be viewed as transient nutrient storage compartments absorbing nutrients during the growing season and releasing large amounts at senescence [13]. However, in subsurface flow wetland, plant uptake and subsequent harvesting were identified as the major phosphorus removal mechanism and the life of a system can be extended by postponing phosphorus saturation of the wetland [14]. 
In constructed wetlands, proportion of phosphate removal can also be attributed to nutritional uptake by bacteria, fungi and algae [2].

- Precipitation of insoluble phosphates in soil or root-bed media:

Two types of phosphate retention mechanisms may occur in soils or rootbed media: chemical adsorption onto the medium and physical precipitation of the phosphate ion. Both result from the attraction between phosphate ion and ions of $\mathrm{Al}, \mathrm{Fe}$ or $\mathrm{Ca}$ and terminate with formation of various iron phosphates $\quad(\mathrm{Fe}-\mathrm{P}), \quad$ aluminum phosphates (Al-P) or calcium phosphates (Ca-P).

\section{2- HYDROLOGY:}

The fluctuating water balance and detention time, due to evapotranspiration and rainfall, play an important role in the design and operation of constructed wetland. But when recirculation of wastewater inside the wetland is to be considered, the recycled quantity will have the major effect on water balance and detention time.

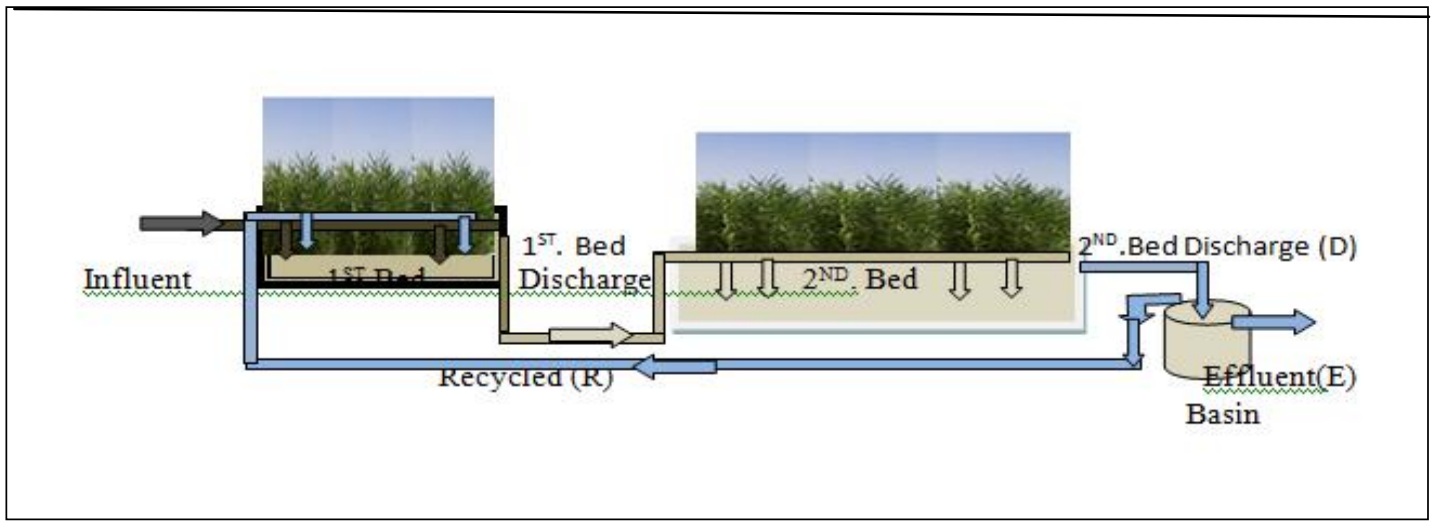

Fig (1) Influent, discharge from cells, recycle and effluent flow diagram 


\section{Journal of Petroleum Research \& Studies}

Equation

(1)

represent

no

recirculation was taken place

(dF./ dt. $=F_{\text {in }}-F_{\text {out }}+F_{\text {rain }}-F_{\text {ev }}$ ),

The above equation can be expressed when recirculation of effluent is implemented (Fig 1), as follow:

$\mathrm{dF} / \mathrm{dt}=\left(\mathrm{F}_{\text {infl }}+\mathrm{R}\right)-\mathrm{D}+\mathrm{F}_{\text {rain }}-\mathrm{F}_{\mathrm{ev}}$

Where $\mathrm{dF} / \mathrm{dt}=$ change in water volume per unit of time, $F_{\text {in }}=$ influent wastewater flow rate (into wetland), $\mathrm{F}_{\text {out }}=$ effluent wastewater flow rate (out of wetland), $\mathrm{F}_{\text {rain }}=$ rain flow rate into wetland, $\quad \mathrm{F}_{\text {evap. }}=$ evapotranspiration rate, $\mathrm{R}$ is the recycled rate, $\mathrm{D}$ is the discharge from $2^{\text {nd }}$. Cell

The detention time with recycling will be less than that without recycling, if the capacity (volume) of the cells is kept the same, as shown below:

$\mathrm{T}_{\mathrm{D}}=\mathrm{P} * \mathrm{~V}$ bed $/ \mathrm{D}$

Where, $T_{D}$ is the average detention time, $\mathrm{P}$ is the porosity of substrate material, $\mathrm{V}_{\text {bed }}$ is the volume of reed bed $=$ [surface area $\left(\mathrm{m}^{2}\right) *$ depth of substrate material $(\mathrm{m})], \mathrm{D}$ is the average discharge (of influent + recycled) from $2^{\text {nd }}$.Cell in $\mathrm{m}^{3} /$ day.

When some discharge from the $2^{\mathrm{ND}}$. cell is recycled back, the detention time of the discharge from cells and of the effluent is shown in table (2) \& chart(1) and it was calculated as follow:

The quantity of effluent discharged from basin consists of two components, one directly from influent and the other from recycled quantity. For a good approximation the effluent assumed to consist of :

-The influent portion which has not been recycled (discharged directly with effluent) that is equivalent to a quantity equal to $E^{*}(E / D)$ have a detention time equal to TD,(Fig 2)

- The recycled portion in the effluent, which has been recycled more than once, is eqivalent to a quantity equal to $E^{*}(R / D)$ but this portion will have a detention time $\geq 2$ TD.(Fig.2) 
From that the detention time of the discharged effluent (E) will be equal to $T_{D}$ with a portion having a quantity equal to $\mathrm{E}^{*}(\mathrm{R} / \mathrm{D})$ will have extra detention time $\geq \mathrm{T}_{\mathrm{D}}$. (Fig.2)

\section{2- EXPERIMENTAL WORK}

\section{The effect of recycling part of}

the effluent from a vertical subsurface flow wetland back to the wetland, on the nutrient removal efficiency, was studied in this research work. The existing two steps vertical subsurface flow (VSSF) pilot plant used in the previous work to study the implementation of such ecological method in the treatment of municipal wastewater [1], was used in this work with some modification made to the design in order to allow for the recycling to take place.

The wastewater influent to the running, vertical subsurface flow, pilot plant (July2006-July2009) was stopped in August 2009 for three week to allow for the required modification for the new research work to be carried out. The depth of each cell, for the previous research work, was designed so that the edges (banks) of the cells is about $30 \mathrm{~cm}$ higher than the substrate layers in the cells, to allow for any future increase in the influent quantity to the cells.

Construction and modification of the pilot plant:

1- Pumping station was already exist, from previous work, to transfer $2 \mathrm{~m}^{3}$ /day of wastewater, from the nearest manhole, to the $2 \mathrm{~m}^{3}$ storage tank.

2- $2 \mathrm{~m}^{3}$ Storage tank also exist from previous work, and is used to feed the $1^{\text {St }}$. cell of the Vertical Subsurface Flow pilot plant. The feeding to $1^{\text {St }}$.cell was done by gravitational force, in two doses $\left(1 \mathrm{~m}^{3} /\right.$ dose $)$ starts at $8 \mathrm{AM}$ and $4 \mathrm{PM}$ each day.

3- The $1^{\text {St }}$.cell of VSSF, from previous work, has a surface area of $15.75 \mathrm{~m}^{2}$ and $50-55 \mathrm{~cm}$ depth of gravel substrate layers and lined with PE sheets. The influent wastewater from the storage tank was distributed on the surface of the gravel layers by perforated $(\varnothing 25 \mathrm{~mm})$ PVC pipes and at the bottom of the cell a perforated pipe $(\varnothing 25 \mathrm{~mm})$ was installed to drain 


\section{Journal of Petroleum Research \& Studies}

the treated water and direct it to the $2^{\mathrm{Nd}}$. Cell through level controlled arrangement. The modification required for effluent recirculation to take place includes installing an interval pump at the basin (Fig1 \& Photo 5) to recycle portion of the discharged water from the $2^{\mathrm{Nd}}$. Cell back to 1st. Cell through ( $\varnothing 25 \mathrm{~mm})$ PVC and distributed on top of the substrate layers through the perforated last part of the pipe.

4- The $2^{\mathrm{Nd}}$. Cell (photos $2,3 \& 4$ ) with $35 \mathrm{~m}^{2}$ surface area, which was used in the previous research work [1], remained unaltered which includes $30 \mathrm{~cm}$ layer of washed sand ( $\varnothing 1-$ $2 \mathrm{~mm}), 10 \mathrm{~cm}$ layer of gravel $(\varnothing 10-$ $20 \mathrm{~mm}), 10-20 \mathrm{~cm}$ layer of gravel $(\varnothing 30-40 \mathrm{~mm})$ and $(\varnothing 25 \mathrm{~mm})$ PVC perforated drainage pipe.

5- A basin $\left(1 \mathrm{~m}^{*} 2 \mathrm{~m}^{*} 1 \mathrm{~m}\right.$ height $)$ to hold $2 \mathrm{~m}^{3}$ of discharge water was built and lined with PE sheets. The top surface of the basin was made $10 \mathrm{~cm}$ below the overflow pipe of the $2^{\mathrm{Nd}}$. Cell and a pump with the necessary connections was installed to recycle, in intervals, portion of the effluent from the basin back to the $1^{\text {st }}$. cell through a $(\varnothing 25 \mathrm{~mm})$ PVC pipe and than a perforated distribution pipe over the surface of the $1^{\text {st }}$. cell. The overflow from the basin was directed to irrigate the trees in the vicinity.

6- Flow meters were connected to the pipes carrying the recycled and effluent (discharged from basin) water to check and correct any deviation from the designed hydrology.

After the completion of the modification the wastewater was introduced continuously to make the two cells saturated with water, by keeping the storage tank full all the time, until the effluent start to flow out of $2^{\mathrm{Nd}}$. Cell. After that the designed influent of $2 \mathrm{~m}^{3} /$ day was started to be introduced, by gravitational force, to the $1^{\mathrm{St}}$. Cell in 4 doses, 6 hrs between each dose and each dose was about 500 litres. The $1^{\text {st }}$. dose starts at $8 \mathrm{AM}$ and after $4 \mathrm{hrs}$ of each dose the recirculation interval pump starts for 12 minutes to transfer 120 litres of effluent for each dose. The measured 


\section{Journal of Petroleum Research \& Studies}

average flow rates from the storage tank to the $1^{\text {St }}$. Cell was about 5 liter/min and the average pumping rate

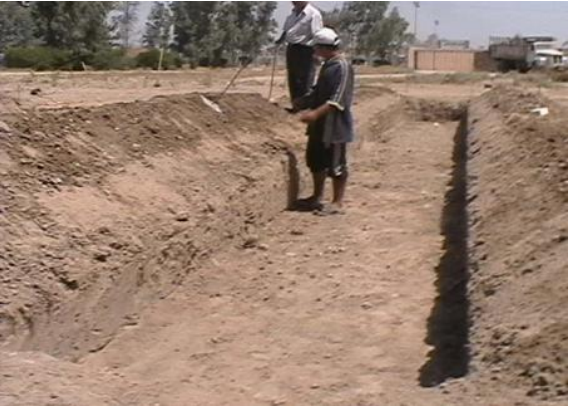

St. Cell during construction 1 PPP06/2007

Photo ( 1)

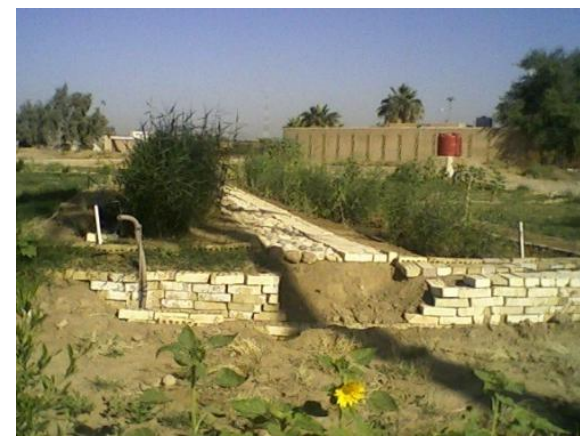

Reed plants on $03 / 2008$

Photo (3) of the interval recirculation pump was

10 liter / minute.

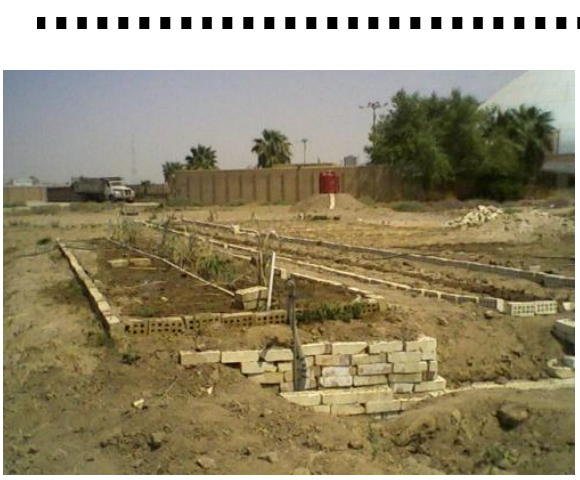

$1^{\text {st }} \& 2^{\text {nd }}$. Cells after construction and reed plantation $08 / 2007$ Photo (2)

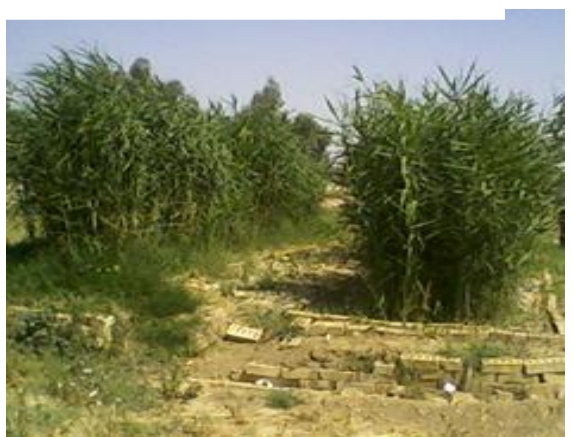

Plants height in the two cells on $01 / 2009$ Photo (4)

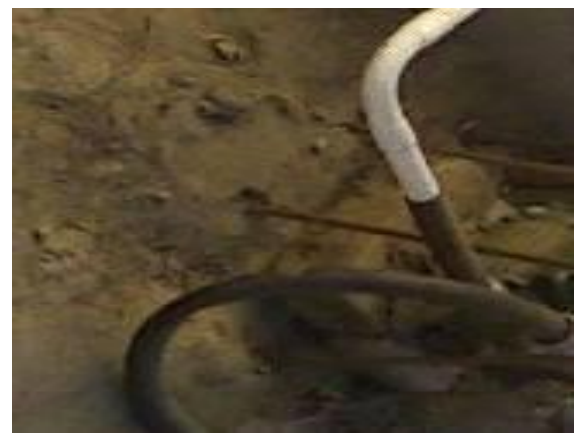

Interval recycling pumping arrangement at the basin Photo (5) 


\section{Journal of Petroleum Research \& Studies}

Table (2): Detention time and flow rate measurement in each cell and the plant when influent $=2 \mathrm{~m} 3 /$ day and effluent recycle from $2^{\text {nd }}$ cell $=0.5 \mathrm{~m}^{3} /$ day

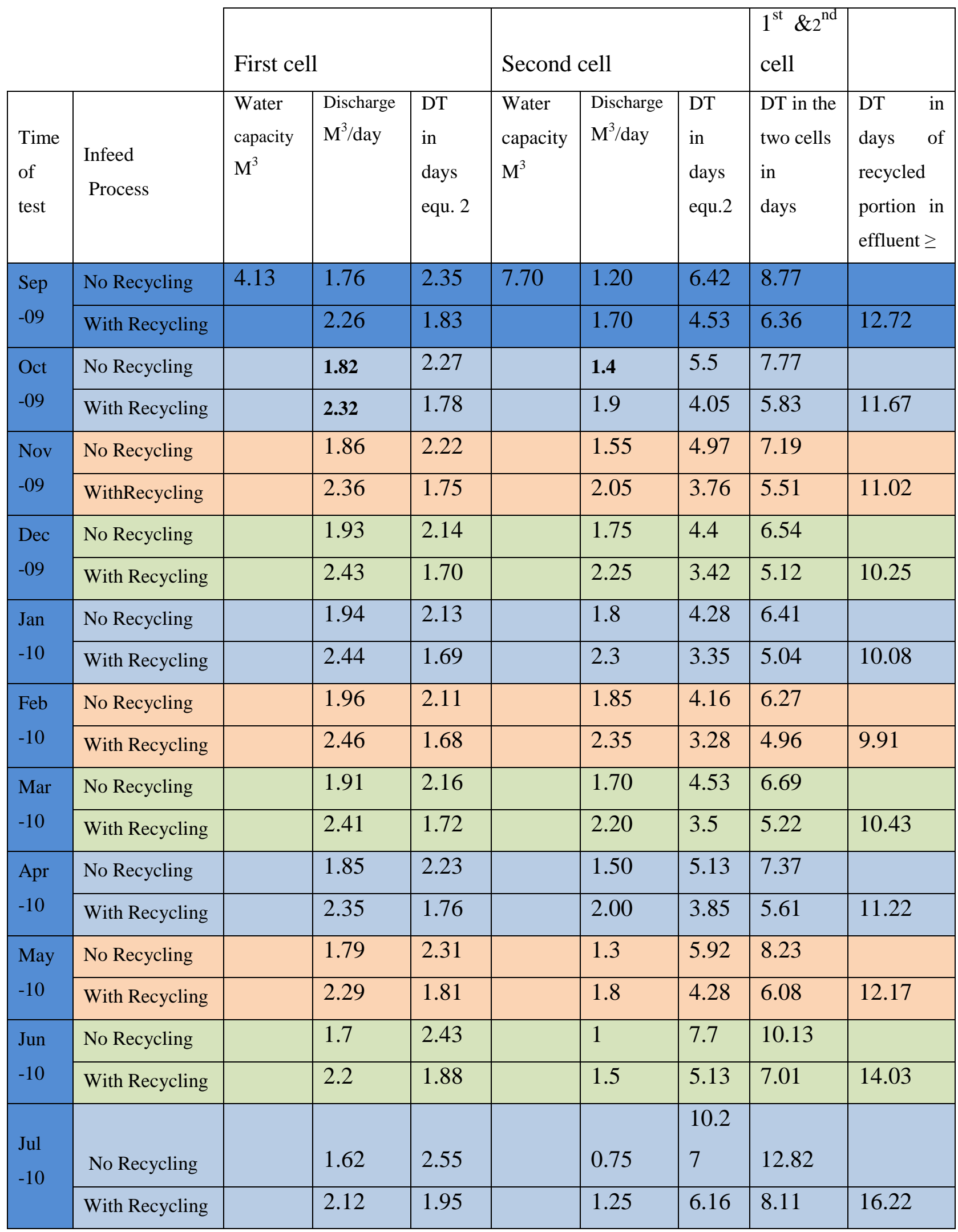




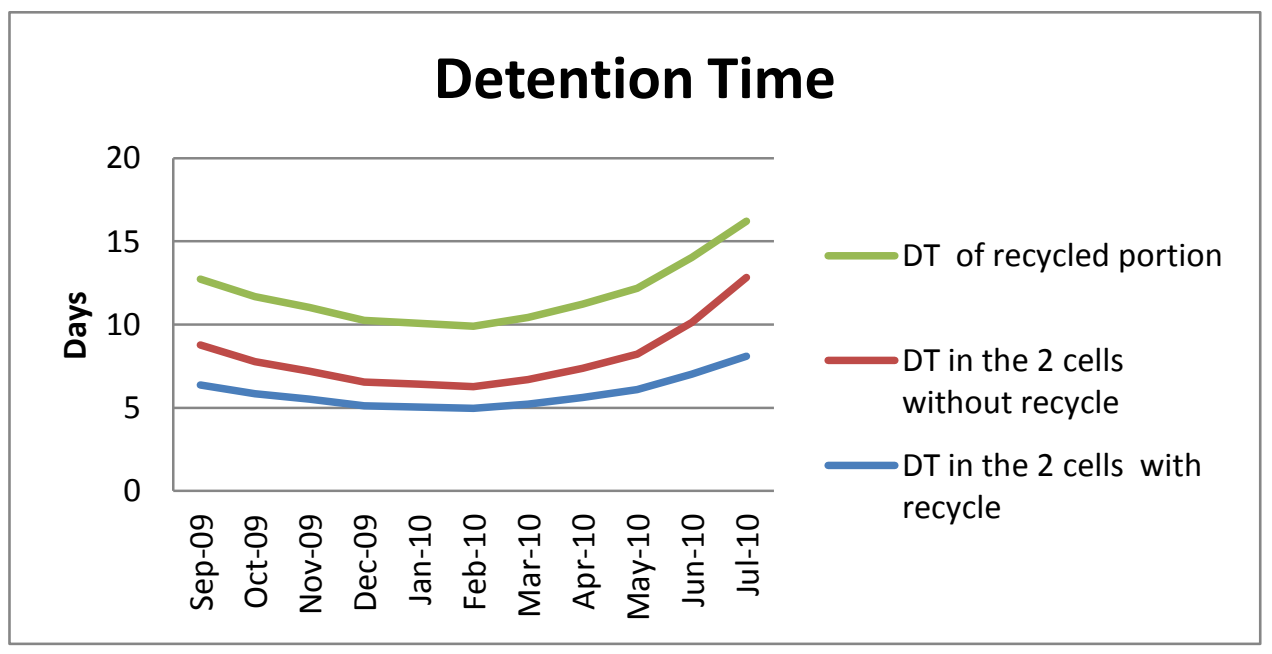

Chart(1) : Detention time with and without recirculation of effluent

Table(3) : Pollutant removal with $0.5 \mathrm{~m}^{3} /$ day recycling.

\begin{tabular}{|c|c|c|c|c|c|}
\hline \multirow{2}{*}{$\begin{array}{c}\text { Type of } \\
\text { test }\end{array}$} & \multicolumn{4}{|c|}{ Date of test } & \multirow{2}{*}{$\begin{array}{c}\text { Previous work } \\
\text { without recycling } \\
\text { on same plant }\end{array}$} \\
\hline & Test for & Nov.09 & Mar.10 & July 10 & \\
\hline \multirow{3}{*}{$\mathrm{BOD}_{5}$} & Influent $\mathrm{mg} / \mathrm{l}$ & 450 & 460 & 460 & 450 \\
\hline & Effluent $\mathrm{mg} / \mathrm{l}$ & 18 & 17 & 18 & 22 \\
\hline & $\%$ removal & 96 & 96 & 96 & 95 \\
\hline \multirow{3}{*}{ TSS } & Influent $\mathrm{mg} / \mathrm{l}$ & 295 & 300 & 300 & 290 \\
\hline & Effluent $\mathrm{mg} / \mathrm{l}$ & 9 & 9 & 8 & 9 \\
\hline & \% removal & 97 & 97 & 97 & 97 \\
\hline \multirow{3}{*}{$\mathrm{NO}_{3}-\mathrm{N}$} & Influent $\mathrm{mg} / \mathrm{l}$ & 0.85 & 0.80 & 0.82 & 0.80 \\
\hline & Effluent $\mathrm{mg} / \mathrm{l}$ & 0.38 & 0.32 & 0.33 & 0.47 \\
\hline & \% removal & 55 & 60 & 60 & 41 \\
\hline \multirow{3}{*}{$\mathrm{NH}_{4}-\mathrm{N}$} & Influent $\mathrm{mg} / \mathrm{l}$ & 125 & 120 & 120 & 120 \\
\hline & Effluent $\mathrm{mg} / \mathrm{l}$ & 48 & 44 & 42 & 70 \\
\hline & $\%$ removal & 62 & 63 & 65 & 39 \\
\hline \multirow{3}{*}{$\mathrm{TP}$} & Influent $\mathrm{mg} / \mathrm{l}$ & 9.5 & 9.3 & 9 & 8 \\
\hline & Effluent mg/l & 3.6 & 3.8 & 3.6 & 4.5 \\
\hline & \% removal & 62 & 59 & 60 & 44 \\
\hline
\end{tabular}


(1) Without recycle

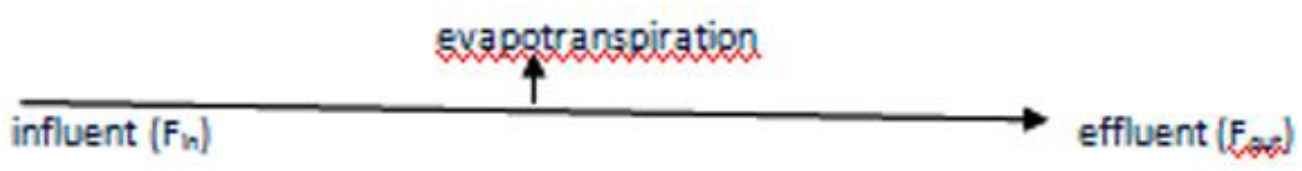

(2) Recycling processesjust started

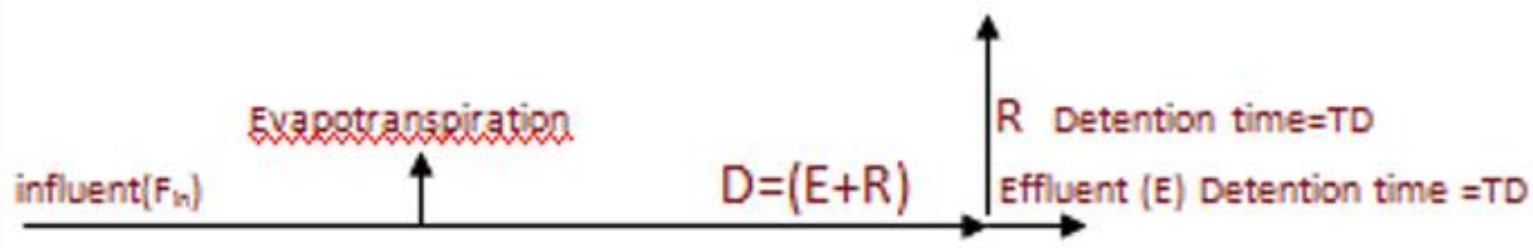

(3) With recycle

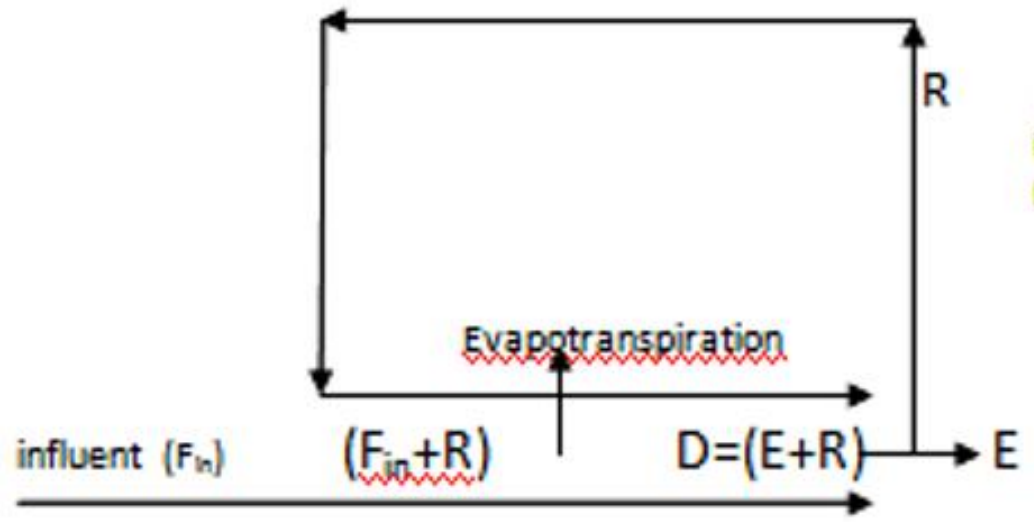

$B=[R / D)^{*} R+(E / D) * R$

DT of component $(R / D)^{\bullet} R z 2 T_{0}$

DT of component $(E / D)^{*} R=T_{0}$

Effluent $(E)=[R / D)^{*} E+(E / D) * E$ DT of component[R/D $]^{\star} E \geq 2 T_{0}$ DT of component $(E / D)^{*} E=T_{\text {。 }}$

Effluent Consists of 2 components one from $\left(F_{i z}\right)$ and the other from $(R)$

The quantity of the component from $F_{i=1}$ is as sumed to $b_{e}=t_{0}(E / D){ }^{*} \mathrm{E}$ which have past the system once therefore have detention time $=T_{D}$

The component from $R$ is as sumed to be equal to $(R D)^{8} \mathrm{E}$ which when pass for the first recycle or the first day of ruming the system it will have detention time equal to TD (see 2 above), but when the recycling operation contimue the component of the recycled quantity in the effluent will have detention time $\geq 2 \mathrm{TD}$ (see 3 above)because it has pas sed more than one time in the system and each time the recycled quantity passes the system it will add a value $=$ to TD to its detention time. This finding was postulated by the author and not found in any reference.

Fig.(2) : Detention time DT of effluent with and without recycling 


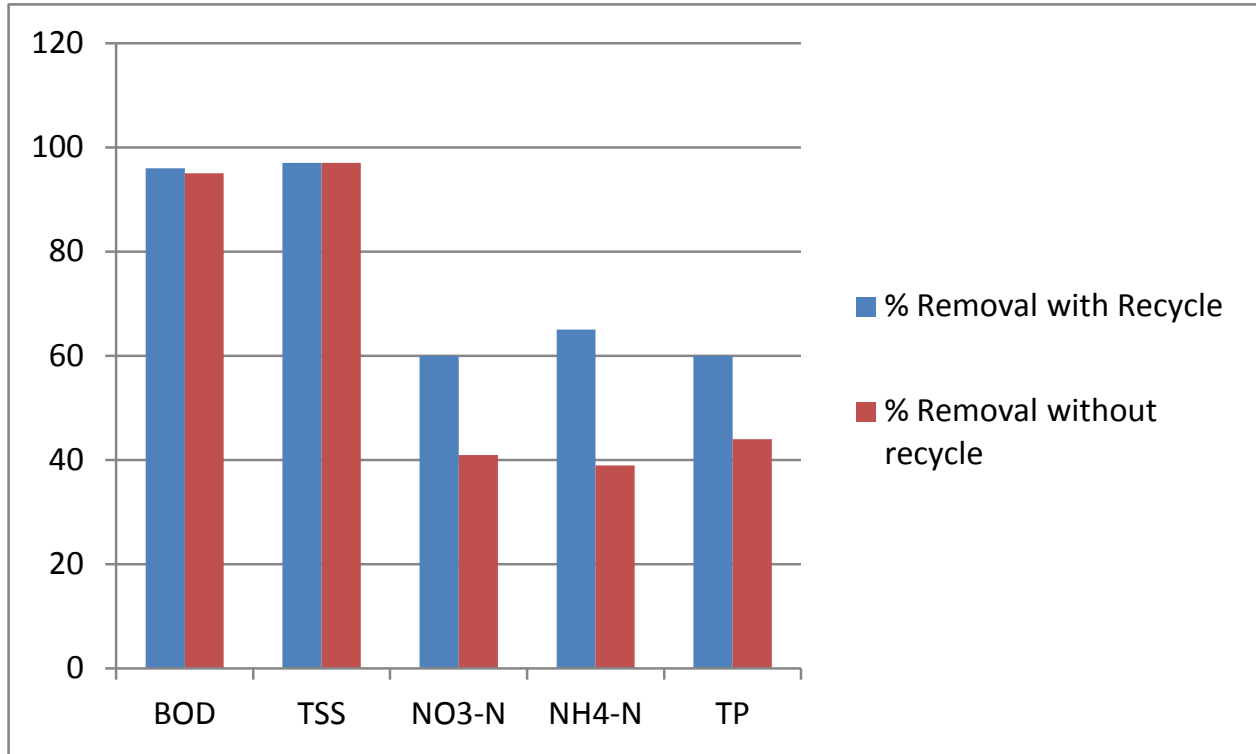

Chart (2) : Effect of recycling on pollutant removal

\section{$\underline{\text { Results \& Discussion: }}$}

The hydrological process in the

wetland, the water balance and detention time in each cell and for the whole system were measured as follow:

1-The discharged effluent from the $2 \mathrm{~m}^{3}$ basin was measured from day to day and the average monthly discharge is recorded (Table 1). 2-The rainfall was negligible during winter time. Equation (2) becomes, when $1^{\mathrm{ST}}$. \& $2^{\mathrm{Nd}}$. Cells kept saturated;
dF./ dt. $=\left(F_{\text {in }}+\mathrm{R}\right)-\mathrm{D}-\mathrm{F}_{\text {evap }}=0$

\section{OR}

$\mathrm{dF} / \mathrm{dt} .=\mathrm{F}_{\text {in. }}-\mathrm{E}-\mathrm{F}_{\text {evap }}=0$

Where $(\mathrm{D}=\mathrm{E}+\mathrm{R})$

Therefore, the quantity of water lost in the system as evapotranspiration $\left(\mathrm{F}_{\text {evap }}\right)$ and plant uptake was calculated as the difference between the daily inflow $\left(F_{\text {in }}\right)$ from the storage tank $\left(2 \mathrm{~m}^{3} /\right.$ day $)$ and the monthly average daily effluent discharged ( $\mathrm{E}$ ) from the basin (Table 2). The estimated $F_{\text {evap }}$ in each 


\section{Journal of Petroleum Research \& Studies}

cell was calculated using the assumption that evapotranspiration is proportional to surface area of the cells which have the same plant density.

The quantity of water discharged from $1^{\mathrm{St}}$. to $2^{\mathrm{Nd}}$.cell is than calculated knowing the $F_{\text {in }}=2 \mathrm{~m}^{3} /$ day and the calculated $\mathrm{F}_{\text {evap }}$ from Eq. (4) above (table 2).

The detention time in each cell can now be calculated using Equ.(3)and having in mind that the volume of bed with substrate and its porosity for $1^{\mathrm{ST}}$, and $2^{\mathrm{ND}}$.cells respectively are $\left(8.26 \mathrm{~m}^{3} \& \quad 0.5\right), \quad\left(19.25 \mathrm{~m}^{3} \quad \&\right.$ 0.4)(table2 \& chart1).

3-Samples of the influent, from storage tank, and effluent from the basin of the pilot plant were taken and analyzed at 4 months interval (table $2 \&$ chart2) for $\mathrm{BOD}_{5}, \mathrm{TSS}$, $\begin{array}{llllll}\mathrm{NO}_{3} & -\mathrm{N}, & \mathrm{NH}_{4} & -\mathrm{N} \text { and } & \mathrm{TP} & \text { and }\end{array}$ compared with the results obtained from the previous research work on the same pilot plant but without recycling.

The percentage pollutant removal obtained by the previous work were very good in terms of $\mathrm{BOD}_{5}$ which was $95 \%$ removal, TSS was $97 \%$ removal, but unsatisfactory in terms of $\mathrm{NH}_{4}-\mathrm{N}, \mathrm{NO}_{3}-\mathrm{N}$ and $\mathrm{P}$ which was $39 \%, 41 \%$ and $44 \%$ removal respectively

-The effect of recycling portion of the effluent discharged from the $2^{\mathrm{ND}}$. Cell, of a VSSF constructed wetland back to the $1^{\mathrm{ST}}$. cell on the nutrient removal efficiency of the wetland was studied in this research. Table $3 \&$ chart 2, show an improved removal for all the pollutant under tests compared to the results obtained in the previous research work [1] which was carried out without effluent recycling.

The intermittent feeding of influent and the recycled quantity had good effect on system aeration by dissolving the air trapped in the voids of the substrates before each doss and using it to activate aerobic bacteria.

The Nitrification and denitrification were enhanced by the recycling process. Recycling effluent with low BOD \& COD when mixed with raw wastewater infeed will increase 
system aeration which helps the nitrification process and when most of the oxygen has been consumed, by microorganisms during biological and chemical degradation of pollutant, than the denitrification process will start and transfer the $\mathrm{NO}_{3}{ }^{-}$, ultimately, to $\mathrm{N}_{2}$ gas.

The hydrology condition of the system was good, the water was running in the constructed wetland in a laminar form and the detention time was highest in July and lowest in January as expected due to the effect of evapotranspiration which reaches its highest in July and lowest in January(table $2 \&$ chart 1 ).

The maturity of reed plant and extension of their stems and roots may have a positive influence on:

- Aerobic condition required for the nitrification process and $\mathrm{BOD}_{5}$ removal by supplying more air from the outside atmosphere to the system. - Adsorbing of heavy metal and metal ions on the extended roots of reed plant.

- Increased nutrient uptake by reed plants which results in lowering nutrient in effluent 


\section{Journal of Petroleum Research \& Studies}

\section{References}

1-Alsaad, M., 2008, "Municipal wastewater treatment using reed bed eco-technology" , $1^{\text {St }}$. regional conference of engineering science 5-6, College of engineering/ Nahrain university / Baghdad.

2- Mitsch, J.W\& J.G. Gosselink. 1986. Wetlands. Van Nostrand Reinhold Company, New York. p.536.

3- Greenway M \& Woolley A 1996., Constructed Wetland in Queensland. Murdoch University.

4- Greenway. M \&Woolley. A1999., Constructed Wetlands in Queensland. Ecological Engineering.

5- Greenway.M 1997a. ,Suitability of aquatic macrophytes for constructed wetlands.

Proceedings BNR3 Conference, Brisbone

6- Nature magazine 1995.

7- Godfrey, P.L, Kaynor, ER, Pelczarski, S \& Benforado, J 1985; “Ecological

Considerations in Wetlands Treatment of Municipal Wastewaters", Van No strand Reinhold Company, NY.

8- Sinclair Knight Merz ., 2000, Queensland Department of Natural Resources, Guidelines for Using Free Water Surface Constructed Wetlands to Treat Municipal Sewage.

9- Patrick, W.H. Jr. and K.R. Reddy. 1976. Nitrification-denitrification in flooded soils and water bottoms: dependence on oxygen supply and ammonium diffusion. Journal of Environmental. Quality. 5:469-472.

10- Mitsch, W J \& Gosselink, J G. 1993: Wetlands $2^{\text {nd }}$. Edition, Van No strand Reinhold, NY.

11- Wetzel, R.G. 1983. Limnology. Pp. 255-297. Saunders college publishing. Orlando, Florida.

12- DeBusk, William F. 1999 Wastewater Treatment Wetlands: Contaminant 
Removal Processes. Soil and Water Science Department, University of Florida

13- Bernard, J.M. and B.A. Solsky. 1976. Nutrient cycling in a Carex lacustris wetland. Can. J. Bot. 55:630-638.

14- Lloyd R. Rozema, M.Sc. (excerpt form Master of Science thesis, Brock University, St. Catharines, ON, 2000. 